\title{
ЕЛЕМЕНТИ МЕДІАОСВІТИ У СТРУКТУРІ \\ НАВЧАЛЬНОГО КУРСУ ЛЕКСИКОЛОГІї В ЗАКЛАДАХ ЗАГАЛЬНОЇ СЕРЕДНЬОЇ ОСВІТИ
}

Дика Н. М., Глазова О. П.

\section{ВСТУП}

В умовах реформування вітчизняної системи освіти виникла необхідність урахування особливостей інформаційного суспільства. Законом України «Про освіту» та проєктом Державного стандарту базової середньої освіти передбачено формування в учнів інформаційно-комунікаційної компетентності. Змістова лінія програми Нової української школи «Досліджуємо медіа» передбачає формування в учнів умінь аналізувати, інтерпретувати, критично оцінювати інформацію в медіатекстах i використовувати іiі для збагачення власного досвіду, створювати прості медіапродукти.

За дотримання принципу наступності вчитель-словесник має продовжити розпочате в початкових класах формування в учнів медійної компетентності як важливого складника комунікативної компетентності.

Отже, у програмі враховано взаємодію мовної освіти 3 таким особливим видом освіти, як медійна; вплив медійної грамотності на формування життєво важливих компетентностей учня нині надзвичайно актуальний ${ }^{1}$.

У 2016 р. затверджено нову редакцію «Концепції впровадження медіаосвіти в Україні», головна ідея якої полягає в «підготовці дітей і молоді до безпечної та ефективної взаємодії із сучасною системою медіа, формуванні у громадян медіаінформаційної грамотності й медіакультури відповідно до їхніх вікових, індивідуальних та інших особливостей ${ }^{2}$ ». Проте питання практичного впровадження в школі медійної освіти, кінцевим результатом якої має стати практична медіаграмотність, залишається недостатньо дослідженим.

Метою дослідження $\epsilon$ ознайомлення вчителів-словесників зі шляхами впровадження у шкільний курс лексикології елементів

1 Дика Н., Глазова О. Робота 3 медійним текстом в умовах модернізації навчальних програм з української мови. Педагогічна освіта: теорія $і$ практика. 2019. № 31. C. 40. DOI: 10.28925/2311-2409.

${ }^{2}$ Концепція впровадження медіаосвіти в Україні. URL: https://ms.detector.media/ mediaosvita/post/16501/2016-04-27-kontseptsiya-vprovadzhennya-mediaosviti-v-ukraininova-redaktsiya/. 
медійної освіти, способами формування вмінь розпізнавати дезінформацію, маніпуляцію, пропаганду на основі аналізу вжитих у тексті слів, а також із прикладами лексичних вправ і завдань, виконання яких сприятиме формуванню в учнів практичної медіаграмотності.

Проблеми медіаосвіти та медіаграмотності розкривають у наукових дослідженнях: О. Баранова, О. Баришполець, О. Волошенюк, В. Іванова, В. Лобода, А. Литвин, В. Монастирський, Н. Найдьонова, Л. Наконечна, С. Пензін, Б. Потятиник, Г. Почепцов, В. Різун та ін. Методичні аспекти цієї проблеми розкрито в публікаціях Д. Баранник, М. Вашуленка, Л. Мацько, Т. Симоненко, Г. Шелехової та ін. Питання формування медіакомпетентності педагогічних працівників висвітлюють у своїх працях такі дослідники, як Л. Найдьонова, Б. Потятиник, Г. Онкович та ін. Науковці досліджують питання впливу медіа на окрему особистість і громадську свідомість, маніпулятивні можливості медіа, особливості формування критичного мислення в умовах інформаційних, дезінформаційних і пропагандистських впливів. Попри значну наукову вартісність, виразного зв'язку із завданнями формування засобами шкільної освіти медійної грамотності, конкретних рекомендацій для шкільного вчителя більшість із праць вказаних авторів не містять.

\section{1. Реалізація елементів медіаосвіти під час навчання лексикології в закладах загальної середньої освіти}

Вплив медіа на людину неухильно зростає, зумовлює ії поведінку, вчинки, погляди й цінності - досить часто споживачі медіа сплутують факти з їх інтерпретацією, не можуть скласти оцінку події, правильно визначити іiі причину. Наслідком буває розвиток депресивних станів, неврозів, фобій, а також зниження самооцінки, ослаблення пам'яті й інтелекту.

Розроблена ЮНЕСКО навчальна програма i система компетентностей у сфері медійної та інформаційної грамотності (Media and Information Literacy) об'єднала ці дві різні галузі, цілі і завдання яких можна увиразнити в таблиці 1.

Сучасна стратегія ЮНЕСКО полягає в поєднанні традиційних концептів медіаграмотності й інформаційної грамотності у спільний концепт МІГ і є підгрунтям свободи слова й інформації, оскільки дає громадянам змогу зрозуміти функції засобів масової інформації та інших постачальників інформації, критично оцінювати їхній зміст, а також ухвалювати обгрунтовані рішення, будучи як користувачами, так і виробниками інформації й медіаконтенту. 
Media and Information Literacy

\begin{tabular}{|l|l|}
\hline \multicolumn{1}{|c|}{ Медійна грамотність } & \multicolumn{1}{c|}{ Інформаційна грамотність } \\
\hline розуміти роль та функції медіа в & \\
демократичному суспільстві; & визначати і формулювати інформаційні \\
• розуміти умови, за яких медіа зможуть & потреби; \\
виконувати свої функції; & знаходнти та отримувати доступ до \\
• критично оцінювати контент медіа у & інформації; \\
світлі притаманних їм функцій; & оцінювати та систематизовувати \\
взаємодіяти з медіа для самовираження & інформацію; \\
та участі в демократичних процесах; & використовувати та передавати \\
• актуалізувати навички, в т. ч. роботи з & інформацію із дотриманням етичних \\
ІКТ, необхідні для створення контенту & норм; \\
користувача. & застосовувати навички роботи з ІКТ \\
& для обробки інформації. \\
\end{tabular}

У концепції «Нова українська школа» виокремлено «інформаційноцифрову компетентність», яка має бути набута учнями протягом навчання у школі. Така компетентність включає, зокрема, інформаційну та медіаграмотність, що «передбачає впевнене, а водночас критичне застосування інформаційно-комунікаційних технологій (ІКТ) для створення, пошуку, обробки, обміну інформацією на роботі, у публічному просторі та приватному спілкуванні ${ }^{3} »$.

Термін «медіаграмотність» в Україні визначають як «сукупність знань, навичок та умінь, які дають змогу людям аналізувати, критично оцінювати і створювати повідомлення різних жанрів і форм для різних типів медіа, розуміти й аналізувати процеси функціонування медіа в суспільстві, та їхній вплив ${ }^{4} »$.

Проєктом Державного стандарту базової середньої освіти передбачено формування необхідних в інформаційному суспільстві вмінь ${ }^{5}$ :

- застосовувати «різні види критичного читання текстів/ медіатекстів на відому та нову тематику»;

- знаходити «явну чи приховану інформацію з одного чи кількох джерел»;

- розрізняти «очевидну та приховану інформацію»;

- визначати «актуальність і несуперечливість інформації на основі власного досвіду, критично сприймаючи думки інших»;

- добирати «аргументи для спростування чи підтвердження їх»;

${ }^{3}$ Нова українська школа. Концептуальні засади реформування середньої школи. C. 11. URL: https://mon.gov.ua/storage/app/media/zagalna\%20serednya/nova-ukrainskashkola-compressed.pdf.

4 Медіаосвіта i медіаграмотність : підручник / ред.-упор. В. Іванов, О. Волошенюк ; за наук. ред. В. Різуна. Київ : Центр вільної преси, 2012. С. 10.

5 Державний стандарт базової середньої освіти (проєкт). С. 4-9. URL: https://nus.org.ua/wp-content/uploads/2019/06/standart-1206.pdf. 
- розрізняти об'єктивні факти і суб'єктивні судження в тексті/ медіатексті»;

- розпізнавати «маніпулювання емоціями та протистояти їм»;

- висловлювати та обгрунтовувати «власне ставлення до наданої в тексті/ медіатексті інформації, спираючись на текст/медіатекст»;

- визначати «надійність i достовірність інформації, наводячи окремі докази з тексту і власного досвіду, зважаючи на думки інших»;

- брати участь в онлайн-взаємодії, онлайн-дискусіях, «зокрема виступаючи в ролі їх організатора та модератора», розпізнавати «розбіжності в думках, толерантно обстоювати власну позицію, дотримуючись етикету», розпізнавати «деякі прояви маніпулятивних впливів у цифровому просторі» та уникати їх.

Надзвичайно важливим у цьому контексті $\epsilon$ вимога проєкту Державного стандарту щодо формування вміння висловлювати «свою думку про окремі особливості структури та мовного оформлення тексту щодо їхньої ролі у вираженні змісту тексту/медіатексту ${ }^{6}$ ».

Саме мовне оформлення медіатексту, зокрема використана його автором лексика, дає можливість критично оцінювати зміст і визначати рівень правдивого викладенння інформації. Передусім ідеться про визначення так званих фейкових новин.

Фейкові новини відрізняються двома важливими особливостями ${ }^{7}$ :

- вони видаються «новішими» за інші, тобто відрізняються інформаційно;

- вони емоційніші за інші повідомлення.

Перенесений на емоційний складник акцент відтісняє зміст фейкової новини на другий план. Інформація, переміщена в емоційний контекст, сильніше впливає і краще зберігається в пам'яті. Важливо й те, що фейки мають високу швидкість поширення ${ }^{8}$, а це приваблює споживачів штучно створюваною «актуальністю».

Навмисно створювану, зайву для розуміння змісту висловлення емоційність найлегше розпізнати, визначивши в медійному тексті штучне й недоцільне нагромадження емоційно забарвлених слів.

Опрацьовуючи на уроках медійні тексти, учитель має звертати увагу на роль емоційно забарвлених слів, класифікацію яких можна показати в таблиці 2.

6 Державний стандарт базової середньої освіти (проєкт). С. 4-9. URL: https://nus.org.ua/wp-content/uploads/2019/06/standart-1206.pdf.

${ }^{7}$ Почепцов Г. Емоції створюють інші типи інформаційних потоків для нового людства. URL: https://www.aup.com.ua/yemocii-sozdayut-inye-tipy-informacion/.

${ }^{8}$ Кудрявцева К. Динаміка поширення фейків в соціальному просторі. Критичне мислення в епоху токсичного контенту : збірник статей Восьмої міжнародної науково-методичної конференції. Київ : Академія української преси, 2020. С. 39. 


\section{Класифікація емоційно забарвлених слів}

\section{Групи емоційно забарвлених слів}

\section{Приклади}

\section{Слова - назви почуттів, настроїв та пов'язаних із ними дій, ознак та станів: цирість, жаль, гнів, ніжність, padicmb, пищатись, \\ соромитись, звитяжний; капосний.}

Слова, що містять оцінку предметів, явищ, подій: роботяиий, чепурний, корисно, чудово, силенний, красуня, базікало, розумака, силач, пустобріх, нікчема.

Слова, у яких емоційну оцінку передано за допомогою суфіксів

пестливості, згрубілості; зменшеності, збільшеності: зайчичок; коченятко, ведмедисько, вітрюган; рученьк $a$, ножище; свіюсенький, новісінький, малесенький, здоровенний; страинючий; ЗНЯТИ? слова, що їх уживають дорослі в розмові 3 дітьми: питоньки, спатки.
- Які мої почуття? Розгубленість, досада, навіть обурення. Сиджу на карантині, хвилююся й тривожуся: як тепер $3 \mathrm{HO}$ складати? Переживаю невпевненість $\mathrm{i}$ сум... (3 інтерв'ю).

- «Сторожова застава» - гарний приклад сучасного українського кіно. Дійсно, на початку фільму є жахлива сцена автокатастрофи, але її перекриває якісна постановка боїв та незрівнянні декорації. Кіно цікаве не тільки для підліткової аудиторії (3 рецензіï).

• Плюшеву мишку з пищалочкою, м'ячик-смайлик купіть у нашому магазині для вашого котика, кішечки i кошеняток!

(З реклами).

- «Бабусенько-бабусю, до серця притулюся, для мене ти найкраща голубонько моя», - виконана маленькою конкурсанткою пісенька сподобалась не лише публіці, а й журі конкурсу (3 репортажа).

- Дві години він шкварив з трибуни без перепочинку, теревенив ні про щио, прорікав виразно й лепетав нерозбірливо, галайкотів, балабонив і розпатякував про все на світі (3 відгуку про виступ).

- «Вавилонський ти кухар, македонський колісник, єрусалимський броварник, Олександрійський козолуп, Великого й Малого Єгипту свинар, вірменська свиня, татарський сагайдак, кам'янецький кат, подолянський злодіюка, і всього світу і підсвіту блазень, самого гаспида внук, а нашого Бога дурень» (3 легендарного листа запорожчів турецькому султану). 


\section{Групи емоційно забарвлених слів}

\section{Приклади}

Метафоричні переноси за

подібністю (підкреслюеться

подібність людини до

тварини, рослини, міфічної

особи, предмета.
- 3'явився повний випуск програми, яку турецька телевізійна компанія ТРТ знімала на Хортиці. Зйомки проходили в історико-культурному комплексі “Запорозька Січ”. Ведучий програми, турецький актор Нехар Ерен навчивсятаки володіти різними видами козацької зброї! Тепер він орел, а не козак! (3 газети «День»)

- Чи ти ба, до якого креативу змушує дизайнерів світова криза! Ого, який не лише дешевий, а ще й зручний спосіб винайшли для презентації нової колекції одягу для підлітків! Зветься він «дефіле манекенів» - одяг показують на манекенах або людях у манекенних позах. Ага, саме в такий спосіб представили колекції літо/осінь 2020!

(3 репортажа з показумод).

На нашу думку, під час опрацювання медійного тексту як дидактичного матеріалу учителю варто застосовувати такі популярні в медіаосвіті способи навчальної діяльності, як:

- особистісний (опис емоцій, спогадів, асоціацій, що викликає медіатекст);

- аналітичний (аналіз структури медіатексту, мовних особливостей, думок);

- пояснювальний (формування суджень про медіавитвір загалом чи про його частину);

- оціночний (висновок про його актуальність і правдивість) ${ }^{9}$.

Значні можливості для спостереження за вжитою в медіатексті лексикою надає вивчення таких передбачених чинною програмою тем, як: «Лексичне значення слова» (5 кл.), «Стилі мовлення» (5 кл.), «Поняття про публіцистичний стиль» (7 кл.), «Оцінна лексика» (11 кл.).

9 Медіакультура особистості: соціально-психологічний підхід : навчальний посібник / О. Баришполець та ін. ; за ред. Л. Найдьонової, О. Баришпольця. Київ : Міленіум, 2009. С. 299. 


\section{2. Практика формування в учнів основ медіаграмотності під час навчання лексикології}

Подаємо приклади різнорівневих завдань із застосуванням особистісного, аналітичного, пояснювального, оціночного способів навчальної діяльності.

\section{5 клас.}

Завдання 1. Прочитайте текст, оприлюднений на вебсайті бібліотеки (https://shev.kyivcity.gov.ua/news/9210.html). Визначте $в$ тексті синонімічний ряд. Доберіть основне (опорне, ключове) слово, яке найчіткіше виражає лексичне значення поданих синонімів.

Рідна мова - основа основ духовної культури народу, важливий місточок, за допомогою якого здійснюється зв'язок поколінь.

Нашою мовою мовлять, речуть, розмовляють, говорять, балакають, оповідають, кажуть, гомонять, бовкають, гаркають, гиркають, лепечуть, белькотять поряд із нами й навколо нас люди <...>

У якій мові $є$ ще така багатюща лексика, яка дає змогу вичерпно та влучно охарактеризувати людину, іiі поведінку, наміри, навіть іiі мовлення й ставлення до спірозмовників? Тож вивчаймо мову! Спілкуймося так, щоб цікаво було нам та 3 нами!

*Чи можна сказати, що використані в тексті синоніми розрізняються відтінками значень? Відповідь поясніть.

*Які емоції викликав у вас текст? Значення слова «емоція» з'ясуйте за тлумачним словничком.

*До чого закликає текст? До чого він спонукав особисто вас? Чи можна сказати, що такому впливові сприяли емоції, які текст у вас викликав? Поясніть.

Завдання 2. До кожного з поданих слів доберіть із довідки синоніми, утворені синонімічні ряди запишіть. Чи передають записані слова емоиії, тобто пережсивання людиною свого ставлення до дійсності, душевне переживання, почуття?

Здивування, цікавість, повага, захоплення, зацікавленість.

Довідка. Зачарування, пошана, інтерес, подив, зачудування, захват, шана.

*Iз трьома утвореними синонімічними рядами (на вибір) складіть $i$ запишіть висловлення «Мої враження від екскурсї до музею» для оприлюднення на шкільному вебсайті.

*Яка роль у складеному вами висловленні синонімів? Чи зробили вони висловлення цікавішим для читачів?

6 клас.

Завдання 3. Прочитайте тексти. Визначте стиль кожного, свою думку доведіть. Якому стилю мовлення властиве вживання емоційно забарвлених слів? Визначте такі слова. 
Лисиця звичайна, або руда (Vulpes vulpes, syn. Vulpes fulva) — поширеннй вид роду лисиця (Vulpes) роднни псові (Canidae).

Довжнна тіла тварини - 60-90 см, хвоста 40-60 см, маса тіла - 6-11 кг. Забарвлення

спнни яскраво-руде, часто 3 неясним темним візерунком, черево біле, іноді чорне.

Найчастіше лисиці оселяються на схилах ярів та пагорбів, вибираючи ділянки 3 піщаним

грунтом. Нора, викопана самостійно, звнчайно має кілька вхідннх отворів. У більшості випадків (але не завжди) житло буває добре вкрите густими заростями. У вихованні потомства беруть участь обоє батьків.

Ворогами для лисиці є яструбові (Accipitridae), вовкн (Canis lupus) та ведмедеві (Ursidae). (3 Bikinedii)
Цих рудих хитрунок вважають не лише найкраснвішими, а й найтаємннчішими 3поміж лісовнх тварнн. Їхнє густюще хутро i пухнастий хвостик зазвичай вогненно-червоні.

Побачнвши цю чудову тварннку просто неможливо не закохатися в неї! А які ці лисичкн-сестрички вправні, спритні, хитрі, мудрі! Турботу про рудих дітлахів у лисячій сім'ї беруть на себе обоє батьків. Ще до появи лисенят татусь доглядає за своєю дружиною й допомагає їй облаштовувати лігво. Руді батькі оберегають малечу від вовчиська, ведмедила та зажерливого лиходія яструба (3 вебсайта «Моя планета»).

*Визначте слова із суфіксами, які надають їм зменшувальнопестливого або збільшувально-згрубілого відтінку значень. Які ставлення спричиняють та які емочї викликають слова з такими суфіксами в читачів?

*Чи характерне вживання емоційно забарвлених слів для статей Вікіпедії? 3 якої причини?

Завдання 4. Створіть допис до икільного вебсайту про украӥнських волонтерів, які допомагають медикам подолати пандемію, із використанням слів добродій, милосердя, благодійність. Чи є изі слова емочійно забарвленими? Яка роль таких слів у складеному вами медіатексті?

*Чи є запропоновані до використання слова складними за будовою? Доведіть изе.

*Наскільки актуальними $i$ правдивими $\epsilon$ складені вами й однокласниками дописи? Які емоції й пережсвання викликають вони в читачів? Яка роль у сприйнятті медіатекстів належить емочійно забарвленим словам?

\section{7 клас.}

Завдання 5. Прочитайте текст. Визначте його тему й головну думку. Хто адресати тексту? Чи можна уявити його надрукованим у суспільно-політичних засобах масової інформачї? Проголошеним як виступ у радіо- або телепередачі суспільного змісту?

Коли запитають, чи ви патріот, ви знітитесь і скажете: «Не знаю, хай судять інші». Любов до батьків та до рідної землі - почуття таке високе й безкорисливе, що про нього воліють мовчати. Але не всі. Є люди, які демонстративно, публічно заявляють про свою любов $\mathrm{i}$ б’ють себе руками у груди. 
Чи сумісні з патріотизмом такі почуття, як черствість, заздрість, пиха, нечемність, шукання користі, гнів, неправдивість або зневіра? Якщо ними наділений «патріот» - значить, його патріотизм несправжній.

Слово «патріотизм» асоціюється 3 моральними поняттями, зокрема 3 порядністю. Словесний патріотизм нічого не вартий. Має бути діяльний патріотизм, який себе не афішує, але виявляється на кожному кроці.

Немає другого Дніпра i не буде іншої Батьківщини <..> Батьківщина - ваш дім, і він буде таким, яким ви його зробите. І ви свій дім повинні наповнювати духовністю ( 3 а $С$. Сверстюком).

*Визначте емочійно забарвлені слова. Яка роль таких слів у мовленні?

*3 опорою на таблищю “Стилі мовлення» доведіть, що текст створено в публіцистичному стилі.

*Дотримуючись публічистичного стилю, поясніть різнищю між патріотизмом словесним і діяльним. У відповіді вживайте емоційно забарвлені слова.

Завдання 6. Прочитайте. Лексичне значення виділених слів з'ясуйте за Тлумачним словничком. Визначте стиль висловлення. Звіртеся 3 таблицею «Стилі мовлення».

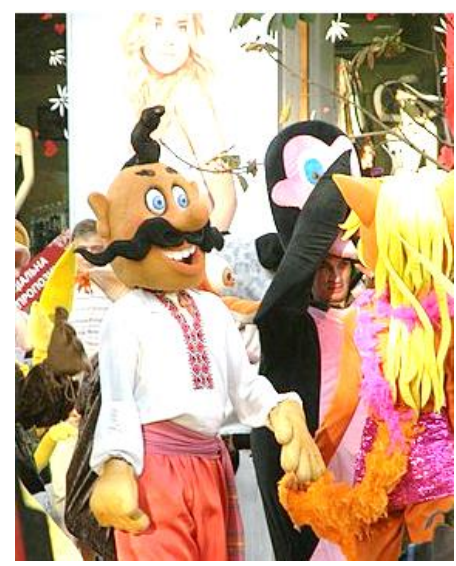

На жаль, не кожен відрізняє від справжнього патріотизму його фальшиву сестру - шароварщину. А її чимало скрізь: на телебаченні, у побуті, а найгірше - у людських мізках.

Шароварщиною називають спекуляцію на національних мотивах, підміну національного його зовнішніми атрибутами. Українську національну культуру намагаються звести до найпримітивніших понять: якщо народний одяг - це обов'язково шаровари, якщо їжа - то передусім 
сало й вареники, якщо народна пісня - то «Несе Галя воду», якщо танець то тільки гопак <..> Якщо йдеться про козака, його зображають як дебелого дядька із шаблюкою й знову-таки в тих самих шароварах.

Хіба ж не шануємо ми минувшини, не пишаємося своєю історією, народним мистецтвом? Українці знають, шанують і бережуть своє коріння. Проте час не стоїть на місці. Українці - сучасна європейська нація. Вони працелюбні й освічені, налаштовані на стрімкий розвиток, відкриті до всього нового. А шароварщина - це звичайна відсутність смаку, що незграбно маскується під національне!

Спроба нав'язливого поєднання майбутнього 3 минулим цілком може прищепити несприйняття всього українського, недовіру до гідного майбутнього українського народу.

Шароварники грають роль щирих українців і закликають робити те саме інших. Проте грати роль українця й бути українцем - різні речі. Справжній українець нікого не наслідує, нікого із себе не вдає, він $є$ сам собою. Він не грається в історію, він ії творить.

Українці посідають гідне місце в колі народів світу (Із журналу «Однокласник»).

*Визначте тему та головну думку тексту. Чи $\epsilon$ текст актуальним? Якою мірою?

*Роздивіться ілюстраиію зі статті украӥнської Вікіпедї «Шароварщина». Наведіть відомі вам зразки шароварщини (пісні, виступи співочих гуртів, мультфільми тощо). Назвіть емоиії та почуття, які викликають у вас такі «витвори»?

8 клас.

Завдання 7. Попрацюйте $y$ групах. Прочитайте уривок зі спілкування на форумі вебсайту «Моволюби».

\begin{tabular}{|c|c|}
\hline Правдоруб & $\frac{\text { Дата: } 15 \text { квітня 2020, середа. }}{\text { Повідомлення } 15}$ \\
\hline $\begin{array}{r}\text { Група: кори } \\
\text { Повідомле } \\
\text { Статус - }\end{array}$ & 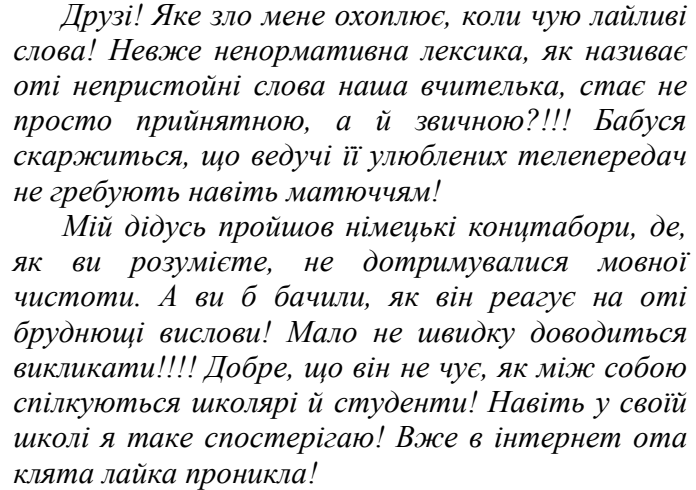 \\
\hline
\end{tabular}




\begin{tabular}{|c|c|}
\hline Особливо справедлива & $\frac{\text { Дата: } 15 \text { квітня 2020, середа. }}{\text { Повідомлення } 22}$ \\
\hline $\begin{array}{c}\text { Група: користувачі. } \\
\text { Повідомлень - } 22 . \\
\text { Статус - offline. }\end{array}$ & 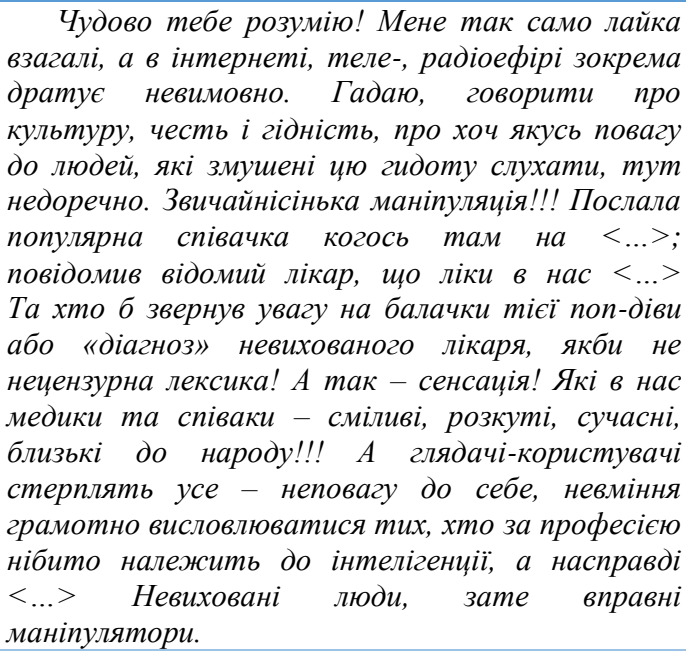 \\
\hline
\end{tabular}

*Включившись в обговорення, сформулюйте й викладіть вамі думки щодо обговорюваного питання.

*Свою позицію обтрунтуйте якнайретельніше. Лексичне значення слова «маніпуляиія» з'ясуйте за онлайн-словником.

*Доберіть нікнейми, щуо відповідають змісту ваших висловлень.

9 клас.

Завдання 8. Прочитайте текст, визначте його тему. Лексичне значення виділених слів з'ясуйте за Словничком термінів.

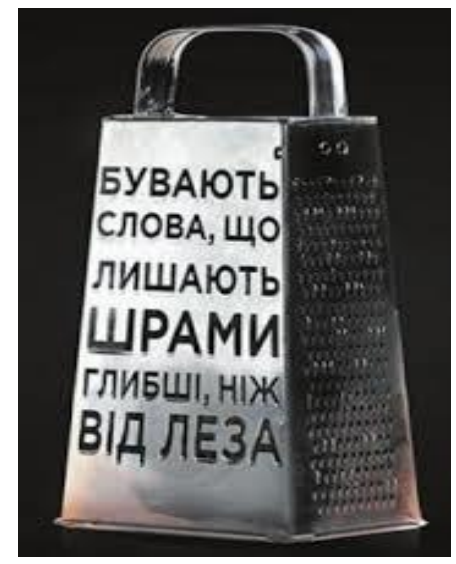


Після Другої світової війни у Європі виникла потреба в ухваленні законодавчих актів, що забороняли б «мову ненависті» (hate speech). Мета цих законів - мир та захист від ксенофобії на європейському континенті.

«Мову ненависті» визначають як «усі види висловлень, які поширюють $<\ldots$..> расову ненависть, ксенофобію, антисемітизм та інші форми ненависті, викликані нетерпимістю, у тому числі у формі агресивного націоналізму і етноцентризму, дискримінації меншин і ворожого ставлення до них, а також іммігрантів». У цьому сенсі поняття «мова ненависті» поширюється на всі висловлення, спрямовані проти особи або групи осіб.

Водночас існує думка, що під категорію "hate speech" має потрапляти не лише агресивна лексика, що закликає до дискримінації чи принижує, а й створення негативних стереотипів щодо певних соціальних груп населення (3 інтернету).

*Визначте в тексті зачин. Домисліть $i$ запишіть кінцівку висновок, ще випливає з усього сказаного.

*Виразно прочитайте текст. Завершіть його висловленням складеної вами кінцівки. Уживайте емоџійно забарвлені слова. Яка роль таких слів у мовленні?

*Чи доводилося вам спостерігати за вживанням «мови ненависті» молодими украӥниями? Стосовно яких груп осіб або окремих людей таку мову вжсиали?

*Роздивіться плакат, створений у межах скерованої проти «мови ненависті» інформаційної кампанії «Слова ранять». Передайте враження від плаката, дайте йому оиінку. Вживайте емоиіийно забарвлені слова.

Завдання 9. Попрацюйте у групах. Використавши мережу Skyре, організуйте та проведіть інтернет-дискусію на тему "Інтернет у житті сучасного учня». Обговоріть питання: «Інтернет зближує людей чи поглиблює самотність?». У виступах уживайте емоційно забарвлені слова.

10 клас.

Завдання 10. Прочитайте поезію Тетяни Добко. Визначте емоційно забарвлені слова. Окресліть ӥхню роль у мовленні, зокрема у спілкуванні за допомогою сучасних технологій.

\section{Мій друже}

Ми загубились у просторі й часі,

Tепер SMS-ки замінники щастя,

Можна нічого уже не казати:

Клікнуть чи «лайк» миттєво послати.

Друже, мій друже! Алло! Де ти є? 
В лісі зозуля кує про своє,

Час не стоїть, він втікає, як знати,

Може, вже завтра не зможем сказати:

«Друже, мій друже! Привіт! Добрий день!»

Вітер навіяв тужливих пісень,

Посмішка щира, родинне тепло,

Як це насправді давно все було...

Як же насправді я скучила, друже,

Разом із вітром душа моя тужить...

Хоч віртуальність не має меж, -

Краще зустрітись, щоб світ наш не щез.

*Як ви розумієте зміст останнього речення? Про який світ idеться?

*Які почуття до співрозмовника можна увиразнити, спілкуючись із викорситанням SMS ma Viber? Чи спроможні емотикони (смайлики) повноцінно замінити слова? Чому?

Завдання 11. Прочитайте. Які емоиї та асоиіації викликають у вас слова «шпрехенфюрери» та «мовні наглядачі», «виправні роботи»? Чи є емоційно забарвленими слова «не жаліти» та «карати»? Поясніть, із якою метою вжито їх у тексті? 3'ясуйте адресатів $і$ мету медійного тексту. Які лексичні засоби вказують на його фейковість?

贯 17 ГРудня, 2019-21:11 Е новини

Фейк: Українські «шпрехенфюрери» за російську мову каратимуть навіть дітей

Українські «шпрехенфюрери» в питанні використання російської мови «не пожаліють навіть дітей»: «мовні наглядачі» за недотримання норм закону про «насильницьку українізацію» збираються штрафувати «навіть дитячі садки і гуртки». 11 грудня агітпроп запустив нову хвилю фейків, спрямованих проти документа про використання української мови і, зокрема, проти призначеної уповноваженої з захисту державної мови Тетяни Монахової. Російські медіа залякують: «карати» за відмову від використання української мови будуть не тільки штрафами, а й «виправними роботами».

*Висловловте свою думку про особливості структури та мовного оформлення медіатексту та їхню роль у вираженні змісту.

\section{1 клас.}

Завдання 12. Прочитайте. Визначте емочійно забарвлені слова. Як вони впливають на сприйняття змісту медіатексту?

Без сучасного й якісно організованого інформаційного простору нації неможлива ii політична єдність і формування національної ідентичності.

Якщо мільйони українських громадян позбавити доступу до всіх i всяких духовних цінностей, націю буде зведено до рівня тубільського племені, забезпеченого хіба що рекламою ритуальних танців шоу-бізнесу та ще «фольклором» у вигляді кримінальних серіалів. Якщо український громадянин буде позбавлений доступу до знання цінностей у найширшому 
сенсі, він не знатиме, чим йому у своїй країні пишатися, - а це почуття, без якого не буває повноцінного громадянства.

Головне національне багатство кожної країни - люди, їхні здібності й потенціали (За О. Забужко).

*Витлумачте значення термінів «духовні цінності», «інформаційний простір». Звіртеся зі Словничком термінів.

*Якою мірою ви згодні з автором тексту? Відповідь аргументуйте.

*Поміркуйте: які з відомих вам каналів телебачення або вебресурсів (сайти, блоги) ознайомлюють користувачів інтернету з духовними цінностями українського народу. Напишіть відгук про передачі (публікації), щзо їх продукує названий вами канал або вебресурс. Використайте у відгуку емочійно забарвлені слова.

\section{ВИСНОВКИ}

Включені до навчального курсу лексикології елементи медіаосвіти мають готувати учнів до грамотної та відповідальної поведінки у світі інформації: навчати орієнтуватися в інформаційних потоках, критично ставитися до кожного медіатексту, мати аргументовану власну позицію щодо його змісту та форми вираження. Із цією метою необхідно ввести відповідний навчальний матеріал до шкільних підручників і посібників, створити актуальні методичні матеріали для вчителів. На часі підготовка й видання сучасного словника медійних термінів для учнів закладів загальної середньої освіти.

\section{АНОТАЦІЯ}

У статті розглянуто аспекти реалізації елементів медіаосвіти під час навчання лексикології в закладах загальної середньої освіти. Подано короткий огляд основних питань упровадження у шкільний курс лексикології елементів медійної освіти, способів формування вмінь розпізнавати дезінформацію, маніпуляцію, пропаганду на основі аналізу вжитих у тексті слів. Виокремлено дослідження науковців про вплив медіа на окрему особистість і громадську свідомість, маніпулятивні можливості медіа, особливості формування критичного мислення в умовах інформаційних, дезінформаційних і пропагандистських впливів.

Охарактеризовано медійну й інформаційну грамотність. Визначено найбільш ефективні шляхи формування медіаграмотності учнів закладів загальної середньої освіти. Наведено приклади різнорівневих завдань i вправ, які сприяють формуванню медійної та комунікативної компетентності. Доведено, що включені до навчального курсу лексикології елементи медіаосвіти готують учнів до грамотної i відповідальної поведінки у світі інформації, навчають орієнтуватися в інформаційних потоках, критично ставитися до кожного медіатексту, мати аргументовану власну позицію щодо його змісту та форми вираження. 


\section{ЛITЕРАТУРА}

1. Нова українська школа. Концептуальні засади реформування середньої школи, 2016 / Міністерство освіти і науки України. URL: https://mon.gov.ua/storage/app/media/zagalna\%20serednya/nova-ukrainskashkola-compressed.pdf (дата звернення: 30.04.2020).

2. Дика Н., Глазова О. Розвиток емоційного інтелекту як важливий компонент методики навчання мови в закладах загальної середньої освіти. Наукові записки Бердянського державного педагогічного університету. Серія «Педагогічні науки»: збірник наукових пращь. 2019. № 3. C. 105-112. DOI: 10.31494/2412-9208-2019-1-3-105-112.

3. Дика Н., Глазова О. Робота 3 медійним текстом в умовах модернізації навчальних програм з української мови. Педагогічна освіта: теорія і практика. 2019. № 31. С. 39-45. DOI: 10.28925/2311-2409.

4. Державний стандарт базової середньої освіти (проєкт). URL: https://nus.org.ua/wp-content/uploads/2019/06/standart-1206.pdf (дата звернення: 29.04.2020).

5. Концепція впровадження медіаосвіти в Україні (нова редакція) / Національна академія педагогічних наук України. URL: https://ms.detector.media/mediaosvita/post/16501/2016-04-27-kontseptsiyavprovadzhennya-mediaosviti-v-ukraini-nova-redaktsiya/ (дата звернення: 30.04.2020).

6. Коропатник М. Медійна та інформаційна грамотність - одна із важливих компетентностей, які має формувати нова українська школа: виклики інформаційного суспільства. Наукові записки Ніжинського державного університету імені Миколи Гоголя. Психолого-педагогічні науки. 2017. № 3. С. 99-106.

7. Кудрявцева К. Динаміка поширення фейків в соціальному просторі. Критичне мислення в епоху токсичного контенту : збірник статей Восьмої міжнародної науково-методичної конференції. Київ : Академія української преси, 2020. 494 с.

8. Медіакультура особистості : соціально-психологічний підхід : навчальний посібник / О. Баришполець та ін. ; за ред. Л. Найдьонової, О. Баришпольця. Київ : Міленіум, 2009. 440 с.

9. Медіаосвіта і медіаграмотність : підручник / ред.-упор. В. Іванов, О. Волошенюк ; за наук. ред. В. Різуна. Київ : Центр вільної преси, 2012. $352 \mathrm{c}$.

10. Найдьонова Л. Оновлення Концепції медіаосвіти: навіщо було потрібне і які зміни внесені. URL: https://ms.detector.media/mediaosvita/ post/16505/2016-04-27-onovlennya-kontseptsii-mediaosviti-navishcho-bulopotribne-i-yaki-zmini-vneseni/ (дата звернення: 28.04.2020).

11. Українська мова : навчальна програма для загальноосвітніх навчальних закладів. 1-4 класи (програми Нової української школи) / 
Міністерство освіти і науки України. URL: https:/mon.gov.ua/ua/osvita/ zagalna-serednya-osvita/navchalni-programi/ navchalni-programi-dlyapochatkovoyi-shkoli (дата звернення: 29.04.2020).

12. Українська мова : програма для загальноосвітніх навчальних закладів. 5-9 класи. Дивослово. 2017. № № 7-8. URL: http://mon.gov.ua/ activity/education/zagalna-serednya/navchalniprogrami-5-9-klas-2017.html (дата звернення: 27.04.2020).

13. Українська мова : програма для загальноосвітніх навчальних закладів. 10-11 класи. Дивослово. 2018. № № 7-8. URL: https://mon.gov.ua/ua/osvita/zagalna-serednya-osvita/navchalni-programi/ navchalni-programi-dlya-10-11-klasiv (дата звернення: 28.04.2020).

14. Почепцов Г. Емоції створюють інші типи інформаційних потоків для нового людства. URL: https://www.aup.com.ua/yemocii-sozdayutinye-tipy-informacion/ (дата звернення: 27.04.2020).

15. Практична медіаграмотність: міжнародний досвід та українські перспективи. Практична медіаграмотність: міжнародний досвід та украӥнські перспективи : збірник статей Шостої міжнародної науковометодичної конференції. Київ : Академія української преси, 2018. 244 с.

16. Dyka N., Mykytenko V., Shkirenko O. Implementation of innovative technologies at the language learning at the New Ukrainian School. New stages of development of modern science in Ukraine and EU countries : monograph. Riga, Latvia : Baltija Publishing. P. 123-140. DOI: $10.30525 / 978-9934-588-15-0$.

\section{Information about the authors:} Dyka N. M., Candidate of Pedagogic Sciences, Associate Professor, Head of the Department of Language and Literature Institute of In-Service Training of Borys Grinchenko Kyiv University 22 a, P. Tychyny ave., Kyiv, 02152, Ukraine

Glazova O. P., Candidate of Pedagogic Sciences, Associate Professor at the Department of Language and Literature Institute of In-Service Training of Borys Grinchenko Kyiv University 22 a, P. Tychyny ave., Kyiv, 02152, Ukraine 